\title{
Interpretation of the anomalous growth of Austfonna, Svalbard, a large Arctic ice cap
}

\author{
Vivienne RAPER, ${ }^{1}$ Jonathan BAMBER, ${ }^{1}$ William KRABILL ${ }^{2}$ \\ ${ }^{1}$ Bristol Glaciology Centre, School of Geographical Sciences, University of Bristol, University Road, Bristol BS8 1SS, UK \\ E-mail: vivienne.raper@bris.ac.uk \\ ${ }^{2}$ Code 972, NASA Wallops Flight Facility, Building N-159, Wallops Island, VA 23337, USA
}

\begin{abstract}
As previously reported, repeat-pass airborne laser altimetry measurements made in May 1996 and May 2002 show a large positive ice-surface elevation change rate over parts of the accumulation area of Austfonna, eastern Svalbard. The maximum growth rate is estimated to be equivalent to a $\mathbf{3 5 - 4 0 \%}$ increase in snowfall over the area of thickening. Thinning is observed at lower elevations. Here we discuss in detail the possible causes of these elevation changes, including ice-cap dynamics and/or firn density changes, and conclude that sea-ice loss producing a localized increase in precipitation over Austfonna remains the most convincing explanation. This study highlights the problems of interpreting relatively short-term altimetry measurements where auxiliary data are limited in both spatial and temporal extent.
\end{abstract}

\section{INTRODUCTION}

It is believed that the Arctic will warm preferentially under global climate change. Detailed knowledge of the change in volume of Arctic glaciers and ice caps is therefore important for predictions of future global sea-level rise (Dowdeswell and Hagen, 2004). Understanding physical processes that produce a volume change is important both for identifying the effect of climate change on ice masses and for predicting future changes. Elevation change rates measured by altimeter surveys can provide a direct estimate of net changes of an ice mass if corrected for vertical motion of the underlying bedrock (Wingham and others, 1998) and variations in densification rate (Zwally and Li, 2002).

The NASA Arctic Ice Mapping (AIM) missions used an airborne laser altimeter (the Airborne Topographic Mapper (ATM)) to conduct repeat surveys over the Greenland ice sheet (e.g. Krabill and others, 1995b, 1999, 2000). Airborne laser altimeters have also been used over other ice masses such as Alaskan glaciers (Arendt and others, 2002), providing reasonably extensive spatial coverage when compared to most in situ techniques.

Mass-balance studies in the Svalbard archipelago have, in the past, mainly focused on local in situ studies of individual glaciers such as Kongsvegen on Spitsbergen (Melvold and Hagen, 1998). However, over the periods 23-24 May 1996 and 20-23 May 2002, airborne laseraltimetry surveys were made over 17 Svalbard glaciers and ice caps (Fig. 1a) using the ATM (Bamber and others, 2005). Results show a large positive ice-surface elevation change rate (average $0.5 \mathrm{~m} \mathrm{a}^{-1}$ ) over $15 \%$ of the accumulation area of Austfonna, the largest ice cap in the archipelago, situated on Nordaustlandet, eastern Svalbard, and this was attributed to loss of perennial sea ice in the adjacent Barents Sea (Bamber and others, 2004).

\section{STUDY AREA}

Svalbard is a Eurasian Arctic archipelago lying in the region $76-80.5^{\circ} \mathrm{N}, 10-28^{\circ} \mathrm{E}$ and with four main islands, Spitsbergen, Nordaustlandet, Barentsoya and Edgeoya. Nordaustlandet and Spitsbergen were surveyed by the ATM (Fig. 1a).
Austfonna is the largest ice cap in the Eurasian Arctic and has an area of $8120 \mathrm{~km}^{2}$ and a maximum altitude of $783 \mathrm{~m}$ (Dowdeswell and others, 1986). The eastern side of the archipelago receives the highest precipitation which, brought by low-pressure systems from the Barents Sea, is 400-800 mm w.e. (Hagen and others, 1993).

\section{OBSERVATIONS OF ELEVATION CHANGE}

The ATM is a conically scanning, airborne laser altimeter operating at a wavelength of $523 \mathrm{~nm}$ (in the blue-green spectral region), with an off-nadir scanning angle of up to $22.5^{\circ}$. This produces overlapping ellipses of data points along-track, giving a relatively wide swath beneath the aircraft that permits easier resurveying (Abdalati and others, 2001).

For the Svalbard survey, aboard the NASA P-3 aircraft, the laser pulse repetition frequency was $5 \mathrm{kHz}$ and the aircraft was operating at an altitude of about $400 \mathrm{~m}$. This gave a swath width of about $150 \mathrm{~m}$ (Krabill and others, 1995b). The scanner rotation speed was $20 \mathrm{~Hz}$ in 2002 and $10 \mathrm{~Hz}$ in 1996, which gave an along-track data point spacing of 3 and $6 \mathrm{~m}$ respectively. Flight-lines are shown in Figure $1 \mathrm{a}$.

Average elevation change rates over the 6 year interval between the two surveys were obtained by comparing each May 1996 observation with May 2002 data that fell within a $2 \mathrm{~m}$ radius. Results were averaged over $300 \mathrm{~m}$ along-track segments to produce estimates of elevation change rates. Absolute ice-surface elevations were obtained with an accuracy of $0.1 \mathrm{~m}$ rms (Krabill and others, 1995a), permitting elevation change rates of $>0.023 \mathrm{~m} \mathrm{a}^{-1}$ to be determined unambiguously (Bamber and others, 2004).

Elevation change rates calculated over Austfonna are shown in Figure 1b. Large thickening rates (average $0.5 \mathrm{~m} \mathrm{a}^{-1}$ ) were observed above elevations of about $450 \mathrm{~m}$ to the southwest, rising to around $650 \mathrm{~m}$ on the northeast side of the ice cap. The maximum growth rate was estimated to be equivalent to a $35-40 \%$ increase in snowfall from the long-term annual accumulation rate, which is $0.4-0.6 \mathrm{~m}$ w.e. (Pinglot and others, 2001) over the area of thickening when corrected from firn to water 


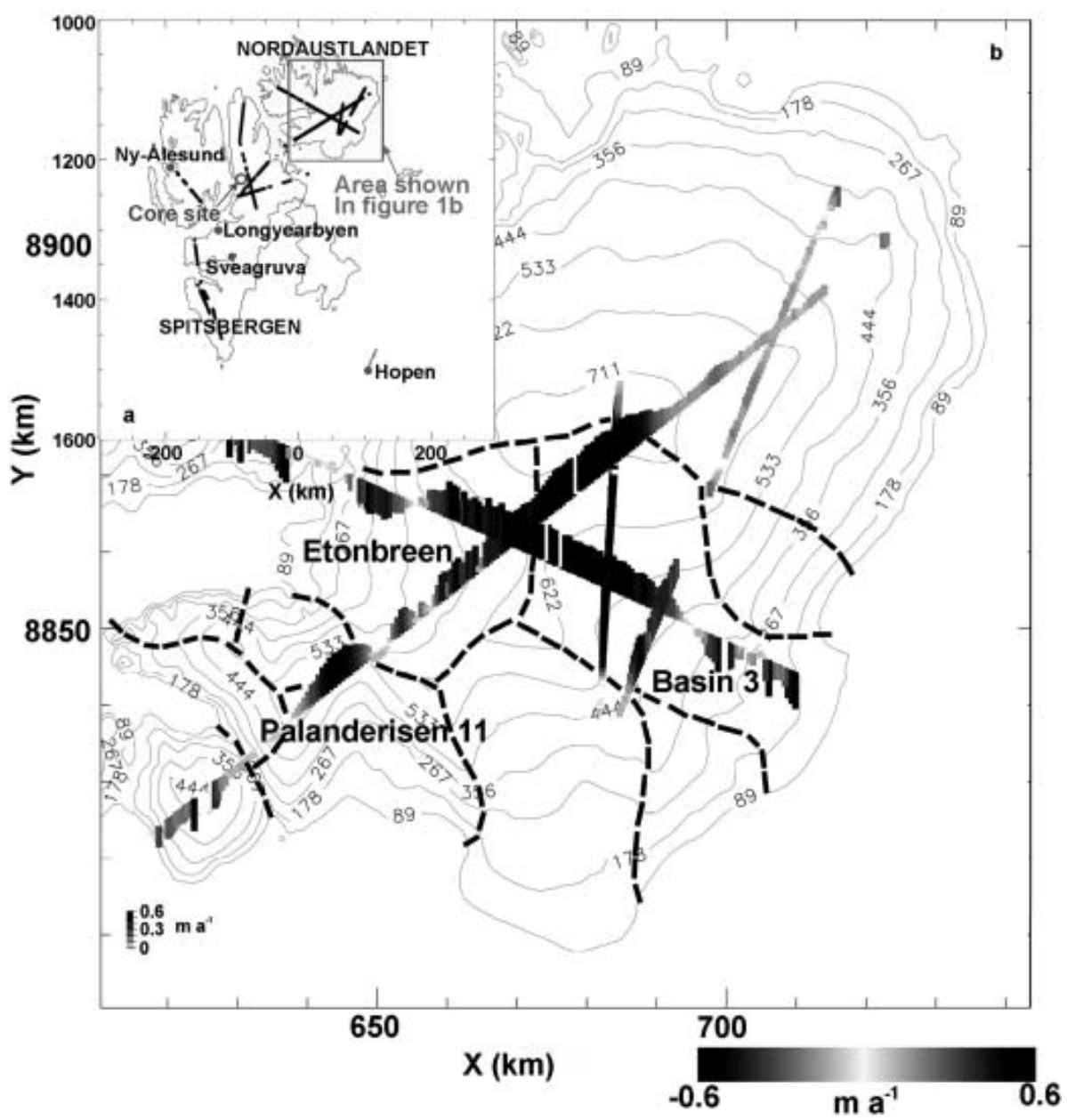

Fig. 1. (a) The Svalbard archipelago showing the flight-lines of the NASA P-3 aircraft during the 1996 and 2002 surveys in black. The meteorological stations for which there were reliable data are shown with solid grey circles. The location of the Lomonsovfonna core site is marked with an unfilled grey circle. Island names are in capitals. The location of the area in (b) is shown by a grey rectangle. (b) Surface elevation change rates over the ice cap of Austfonna overlaid on a contour plot of surface elevation. Contour lines are in metres. Drainage basins in the area of large thickening rates are marked with dashed lines. Elevation change rates are represented by both shading and bar length.

equivalent values (Bamber and others, 2004). Loweramplitude thickening (about $0.1 \mathrm{ma}^{-1}$ ) was observed on the northeast side of the ice cap between 400 and $650 \mathrm{~m}$, with thinning below $400 \mathrm{~m}$ averaging $0.25 \mathrm{~m} \mathrm{a}^{-1}$. The thickening at higher elevations was unexpected given the results of previous mass-balance studies on Svalbard ice masses, which suggest a consistently negative mass balance since 1950. However, these studies have been generally restricted to low-elevation glaciers (Dowdeswell and others, 1995).

\section{INTERPRETATION}

Possible causes of the pattern of elevation change observed on Austfonna can be loosely divided into those resulting from a change in ice-cap dynamics and those related to surface mass balance (and, by definition, climate). Here, we consider the likelihood of both these factors being responsible for the observed elevation changes.

\section{Changing ice dynamics}

Ice-dynamical causes of elevation change may be divided into surge- and non-surge-related velocity changes. Surging was considered as a possible mechanism for causing the observed elevation changes because anywhere between 13\% (Jiskoot and others, 2000) and 90\% (Lefauconnier and Hagen, 1991) of glaciers on Svalbard are surge-type. Furthermore, a number of drainage basins on Austfonna such as Etonbreen and Brasvellbreen are known to have surged since the 1930s (Hagen and others, 1993). The surgerelated mechanism, which may produce positive elevation change rates, results from the velocity slowdown following a surge, and the consequent ice build-up during a surging glacier's quiescent phase. This hypothesis would not, however, produce the pattern of elevation changes observed on Austfonna. The highest rates of elevation change would be expected at lower elevations where the ice thickness had changed most during the surge. Lower rates of elevation change would be expected close to the ice divides (Dowdeswell and others, 1986). This is the opposite pattern of elevation change to that observed.

In addition, a surge-induced signal would be expected to produce differences in elevation change for different basins that have surged at different times. Etonbreen and Basin 3, for example (see Fig. 1b), are believed to have surged in 1938 and 1870, respectively, but show no variation in elevation change rate across the drainage divide. Furthermore, high rates of thickening are also seen 
on Palanderisen 11 (Fig. 1b), but this basin displays no evidence of surge-type behaviour (Lefauconnier and Hagen, 1991). Some Austfonna outlet glaciers are known to have a long quiescent period (Lefauconnier and Hagen, 1991) and could show similar patterns of build-up despite having surged at different times. Basin 3, however, showed surge-type activity between summer 1991 and February 1992 (Dowdeswell and others, 1999). It is difficult to see how these three flow units would produce contemporaneously identical responses in elevation change rates.

For a non-surge-related velocity slowdown, an order-ofmagnitude calculation of the velocity reduction $(\Delta \mathrm{ve})$ needed to produce the observed elevation change was compared to velocity measurements derived from synthetic aperture radar interferometry (Dowdeswell and others, 1999). The interferometry measurements had an estimated error of $0.1 \mathrm{~m} \mathrm{a}^{-1}$ and showed that the outlet glacier velocity of Basin 3 at $15 \mathrm{~km}$ from the ice divide (the approximate limit of the area of thickening) was $10-20 \mathrm{~m} \mathrm{a}^{-1}$ in both February 1992 and January 1994.

The order-of-magnitude velocity reduction $(\Delta v e)$ required to produce the observed elevation change was calculated. Maximum and minimum ice surface areas experiencing high (average $0.5 \mathrm{ma}^{-1}$ ) and moderate (average $0.1 \mathrm{~m} \mathrm{a}^{-1}$ ) rates of thickening were approximated. Bedrock-height and ice-thickness data from Scott Polar Research Institute and Norskpolarinstitutt 1983 airborne radio-echo sounding (RES) missions (Unwin and Wingham, 1997) were used to produce maximum and minimum estimates of ice thickness at the perimeter of the thickening areas. The velocity slowdown required to explain the total thickening on Austfonna was calculated using the equation:

$$
\Delta \mathrm{ve}=\frac{\Delta V}{P d \Delta t^{\prime}}
$$

where $\Delta V$ is the increase in volume (elevation change rate averaged over measured area multiplied by measured area), $P$ is the perimeter length, $d$ is the average ice depth at the perimeter and $\Delta t$ is 6 years. The volumes experiencing moderate and high thickening rates were combined and estimate a velocity decrease of $4.5-12.7 \mathrm{~m} \mathrm{a}^{-1}$ over the entire perimeter of the area of thickening. The large range of values was due to the sparse track coverage available. This represents a minimum decline in velocity of $>20 \%$ when compared to the velocities measured by Dowdeswell and others (1999). Moreover, the actual velocity slowdown required would be larger because mass is removed preferentially through the four to five outlet glaciers rather than equally through the entire perimeter of the thickening area. Even if the summer velocities for Austfonna are 10-60\% higher (Andreasen, 1985) than the winter values in Dowdeswell and others (1999), this would still require a considerable decrease in glacier velocity to produce the observed thickening rates.

\section{Climate changes}

A repeat-pass altimeter survey provides only a snapshot of elevation change over an ice mass. Identifying the timescale over which climatically induced elevation changes occurred is therefore important.

Thinning in the ablation area on Austfonna may reflect the long-term negative mass balance that Svalbard glaciers have experienced over the last few decades (Dowdeswell and others, 1995; Hagen and others, 2003), as suggested for lower-elevation glaciers to the west of Spitsbergen by the ATM (Fig. 1a) (Bamber and others, 2005), where thinning rates are similar to the values measured at lower elevations on Austfonna. Ice cores obtained from the accumulation area and upper ablation area of Austfonna, including from the area experiencing the largest growth, suggest that accumulation rates for the periods 1963-86 and 1986-99 are similar (Pinglot and others, 2001). This implies that any accumulation-induced thickening took place after 1999, requiring thickening rates since then to have been higher than shown in Figure $1 \mathrm{~b}$ because these are mean values calculated for the entire 6 year interval between surveys.

The likely amplitude of interannual variability on Austfonna was examined using a core from the closest available site: the summit of Lomonosovfonna (Isaksson and others, 2001; Fig. 1a). Lomonosovfonna had an accumulation rate of $0.39 \mathrm{~m} \mathrm{a}^{-1}$ w.e. for the period 1951-96, which is slightly lower than the $0.4-0.6 \mathrm{~m} \mathrm{a}^{-1}$ w.e. mean annual net mass balance for the areas of thickening on Austfonna (Pinglot and others, 2001). It was assumed, however, that the variability in the accumulation rate on this ice cap, as a percentage of the mean, would be similar to that on Austfonna. Interannual accumulation data from 1950 to 1997 showed that the 6 year average standard deviation of accumulation was $0.057 \mathrm{~m} \mathrm{a}^{-1}$ w.e. which was $16 \%$ of the 6 year mean $\left(0.37 \mathrm{~m} \mathrm{a}^{-1}\right.$ w.e). This suggests that there is approximately a $98.7 \%$ probability that the average maximum growth rate on Austfonna maintained over 6 years lies outside of the observed accumulation variability for Lomonosovfonna.

If, however, the positive elevation changes on Austfonna were caused by one or more climatically anomalous snowfall events, then this should be recorded in meteorological station data. Weather station data of suitable quality were available for four stations on Svalbard (Hopen, NyÅlesund, Sveagruva and Longyearbyen) (Fig. 1a). Three of these stations, Ny-Ålesund, Sveagruva and Longyearbyen (Svalbard Airport), are situated to the west of Spitsbergen These may not be representative of the climate of Nordaustlandet, which is in the precipitation shadow for air masses from the west (Pinglot and others, 2001), receiving precipitation primarily from the east and northeast (Isaksson and others, 2001). Hopen lies to the east of the Svalbard archipelago, but is some $300 \mathrm{~km}$ to the south of Nordaustlandet. There was no evidence to suggest an accumulation increase on Austfonna from these data. In fact, precipitation was lower during January 1996-January 2002 at Longyearbyen, Sveagruva and Hopen than the long-term mean (1957-2002, 1979-2002 and 1946-2002) by $4.6 \%, 10.8 \%$ and $20.4 \%$ respectively (Fig. 2). These declines are independent of wind direction (Fig. 3). Only $\mathrm{Ny}$-Ålesund shows an increase in precipitation over this period, but this station does not appear to receive precipitation from the east and northeast (Fig. 3). The most dramatic decline in precipitation is at Hopen; it occurs in both summer and winter precipitation, and terminates a trend of increasing precipitation at this station of $\sim 4.3 \mathrm{~mm} \mathrm{a}^{-1}$ between 1946 and 1994. This precipitation decrease is unlikely to be due to undercatch since it is supported by a decrease in the number of days experiencing low $(<1010 \mathrm{hPa})$ sea-level pressure over the same period. 


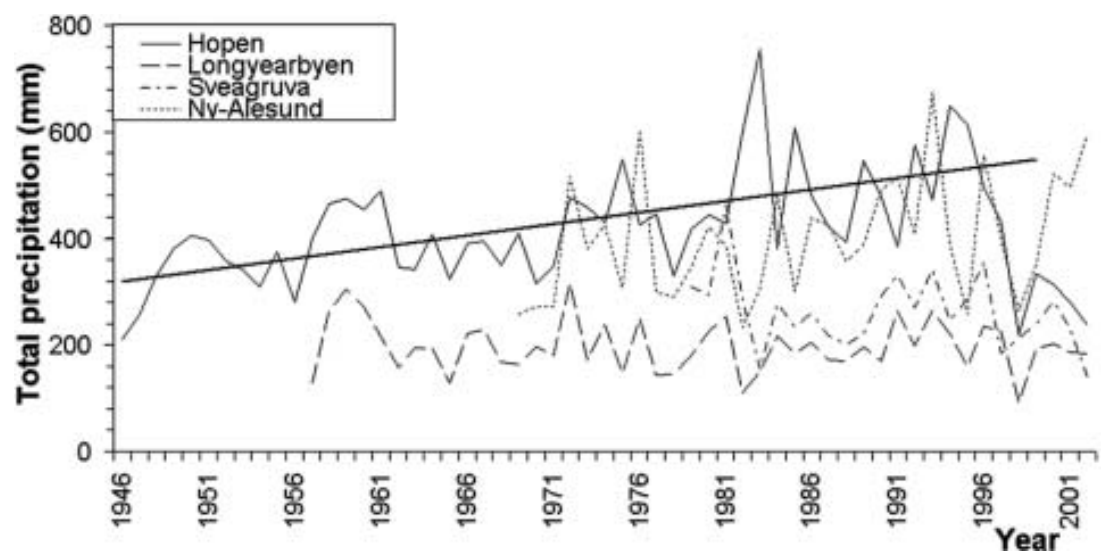

Fig. 2. Total annual precipitation at all four meteorological stations calculated from precipitation measurements measured between two and four times daily.

\section{Changes in densification rates}

Changes in meteorological conditions can affect the rate of densification (Arthern and Wingham, 1998); this factor could have affected, at least in part, the elevation change rate observed. Firn densification, for example, appears to explain many of the elevation changes observed by satellite radar altimeters over the Greenland ice sheet (McConnell and others, 2000). This is not a plausible mechanism for producing large elevation change rates in the area of rapid growth on Austfonna, as the firn thickness in this area is estimated to be only 2-4 m (Pinglot and others, 2001) and the maximum growth on Austfonna was around $3 \mathrm{~m}$ over 6 years.

\section{Changes in sea-ice extent}

Changes in sea-ice cover can produce elevation changes localized to particular ice caps by affecting accumulation rates. For example, Krabill and others (1999) note that an

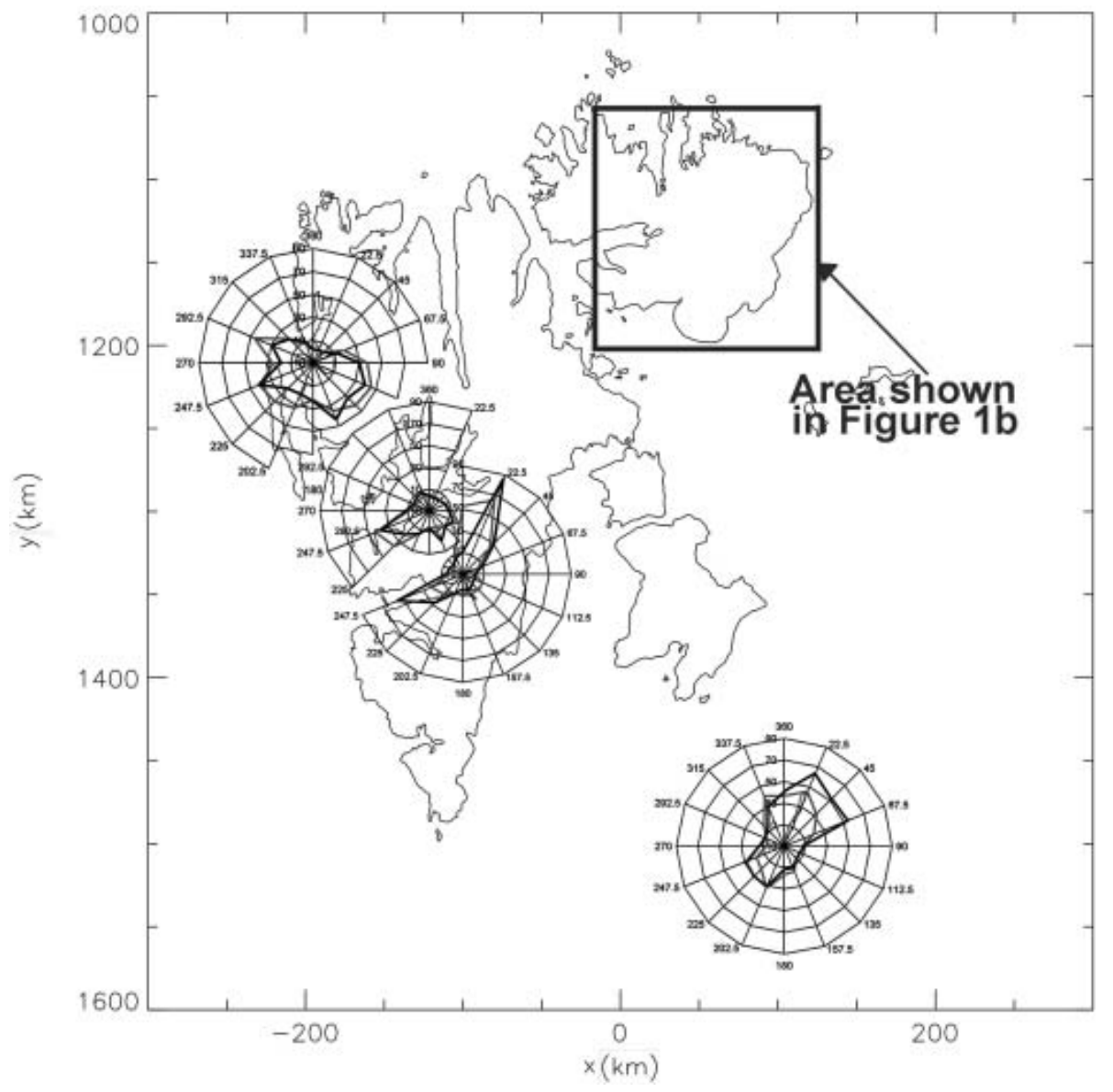

Fig. 3. Average total annual precipitation as a function of wind direction for meteorological stations on Svalbard. The scale of the wind roses is in $\mathrm{mm}$ of precipitation, and the contour lines represent $20 \mathrm{~mm}$. Paler lines show 1996-2000 precipitation for Sveagruva and 1996-2002 precipitation for the remaining three stations. Darker lines show the long-term mean (1979-95, 1969-95, 1959-95 and 1946-95 for Sveagruva, Ny-Ålesund, Longyearbyen and Hopen respectively). 


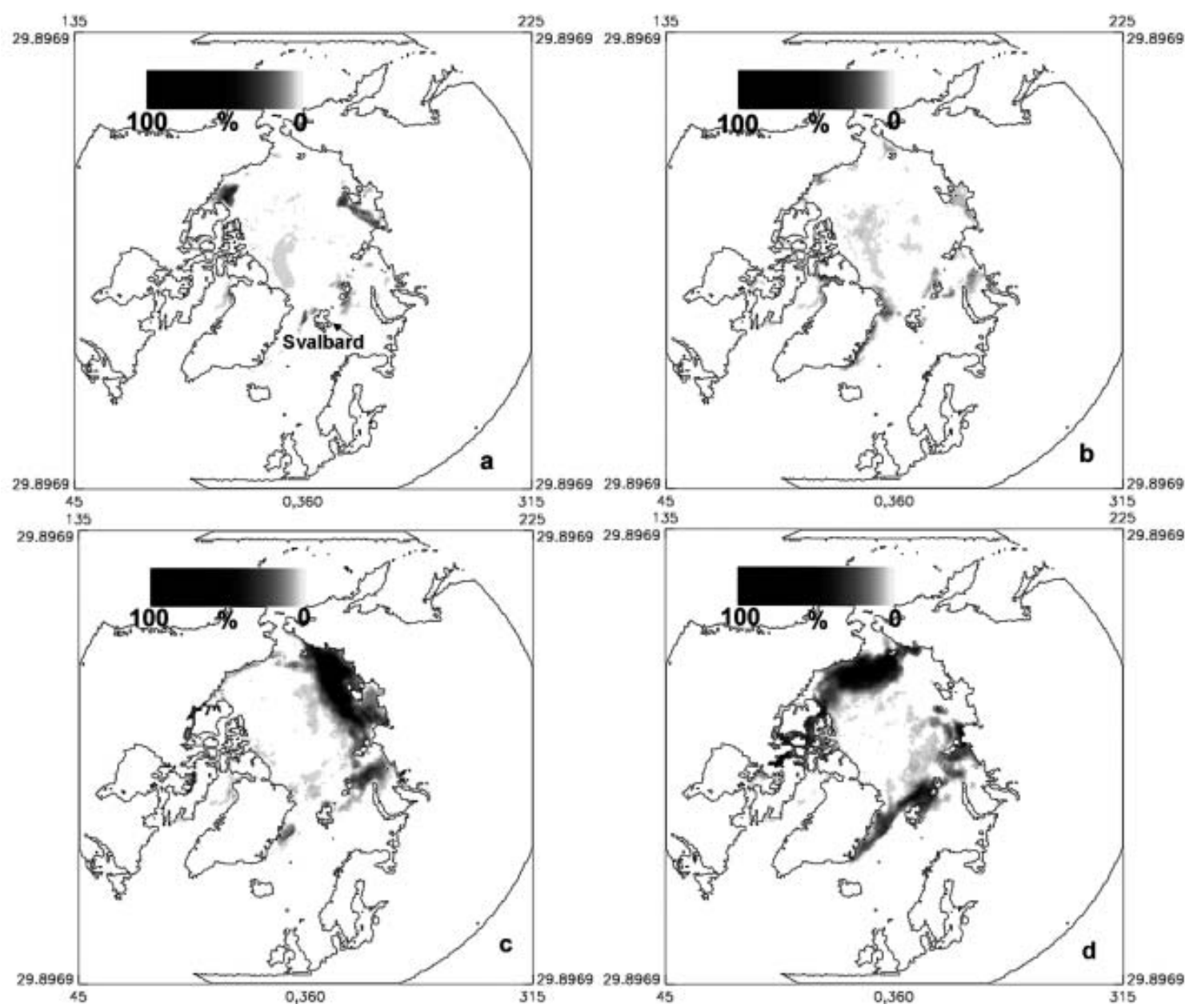

Fig. 4. Percentage decline in perennial sea-ice extent (based on seasonal minimum) for the periods (a) 1979-83, (b) 1984-89, (c) 1990-95 and (d) 1996-2001, derived from passive microwave data using a Bootstrap algorithm and compared to 1979-2001 (long-term mean).

isolated ice cap to the northeast of Greenland was observed to be thickening by $\sim 0.5 \mathrm{ma}^{-1}$, which appeared to be correlated with the extent of the North East Water polynya.

The possible influence of sea ice was investigated using passive microwave radiometer-derived sea-ice concentration data. NASA Nimbus-7 Scanning Multichannel Microwave Radiometer data from 1978 to 1987 and Special Sensor Microwave Imager (SSM/I) data from 1987 to 2001 were used. Here, we used data derived using the Bootstrap algorithm (Comiso, 1995), which is sensitive to thin ice and tends to overestimate summer sea-ice concentrations by $20 \%$ compared to estimates produced by the NASA team algorithm (Singarayer and Bamber, 2003). It therefore potentially provides a conservative estimate of sea-ice decline.

These data show a decline in perennial sea-ice concentrations around Nordaustlandet during the period 19962001 (Fig. 4d), especially during the period 1999-2001. The decline in perennial sea ice close to Nordaustlandet appears to be recent, as it is not replicated during any of the other time periods covered by the data (Fig. $4 \mathrm{a}-\mathrm{c}$ ). The timing of the decline also appears to coincide with the inferred timing of growth suggested by the core data collected from Austfonna (Pinglot and others, 2001). Sea ice acts as an insulator, and its removal increases the area of open water in direct contact with the atmosphere, resulting in high turbulent heat and moisture fluxes from ocean to atmosphere (Dare and Atkinson, 1999). For the
Barents Sea marginal ice zone in May 1999, east of Hopen, given a decrease in ice concentration from $20 \%$ to $0 \%$, the turbulent heat flux would increase by an estimated $225 \mathrm{~W} \mathrm{~m}^{-2}$ (Ivanov and others, 2003). We therefore suggest that the observed decline in sea-ice concentration may have produced an increase in the moisture content of the air passing over exposed areas of open water during the period 1996-2001. This could have caused thickening at higher elevations on Austfonna.

Forecast re-analysis wind-speed data from the European Centre for Medium-Range Weather Forecasts (ERA-40) confirm that prevailing winds over Nordaustlandet are from the east and northeast and are likely to pass over the region of decreased sea-ice concentrations. In addition, the meteorological station data show a weak peak in precipitation around August-September (Fig. 5), suggesting an exposure of open water at this time of year could have a significant effect on precipitation. The largest changes in sea-ice concentrations during the period of the ATM measurements are to the north and northeast of the archipelago and it is likely, therefore, that any local changes in precipitation would be confined to this region.

\section{SUMMARY}

Here we have presented a detailed analysis into causes of anomalous growth on Austfonna, a large Arctic ice cap. Ice dynamics are ruled out as the cause of the observed 


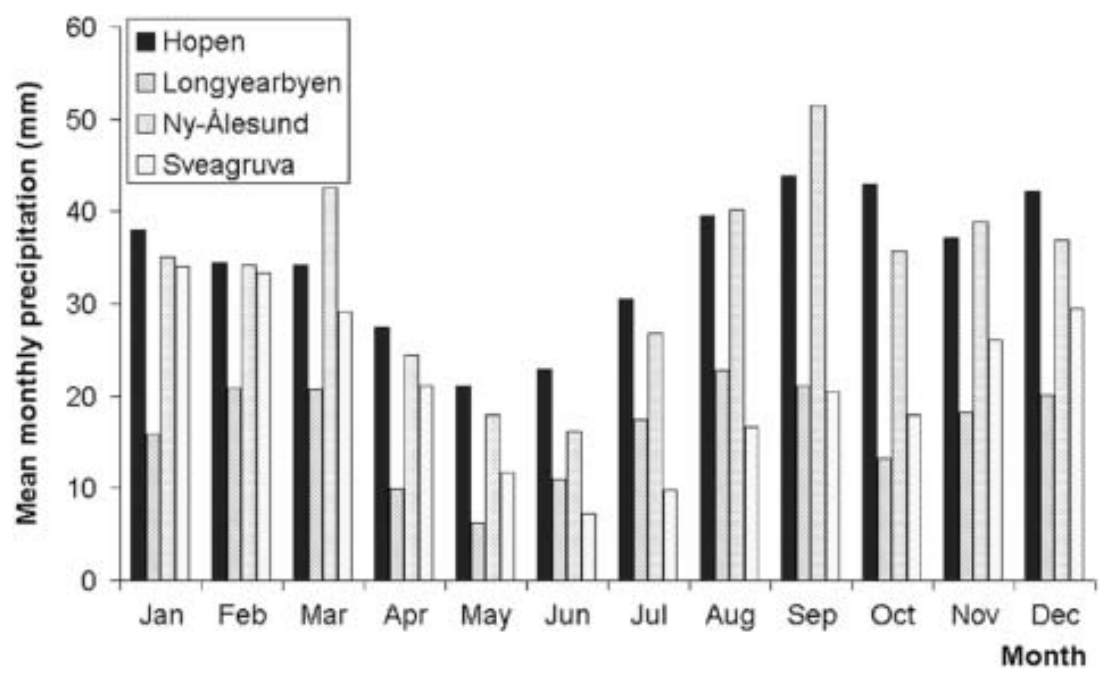

Fig. 5. Average monthly precipitation for meteorological stations on Svalbard averaged over the long-term record (1979-95, 1969-95, 195995 and 1946-95 for Sveagruva, Ny-Ålesund, Longyearbyen and Hopen respectively).

thickening. Growth appears to have begun only recently (1999-2002) and has a high probability of lying outside natural accumulation variability estimated from an ice core on Spitsbergen. No changes in precipitation suitable to produce ice-cap growth are found from weather station records. Since meteorological station data used are obtained some distance from the ice cap, this suggests a localized cause of thickening. We suggest that this is due to the exposure of open water resulting from perennial sea-ice decline around Nordaustlandet over the 6 year period between surveys, increasing the moisture content of airflows from the east and northeast. This study highlights the problems of making interpretations where auxiliary data are limited in both spatial and temporal extent. Future studies should identify whether this thickening continues after May 2002, and if similar patterns of elevation change occurring over this timescale may be observed on other ice caps resulting from Arctic sea-ice cover decline.

\section{ACKNOWLEDGEMENTS}

This work was funded by UK Natural Environment Research Council grant NER/B/S/2000/00083 and NASA's Polar Research Program. We thank the crew of the NASA P-3 aircraft and are grateful for the technical support of R. Mitchell, A. Waller and J. Scott and the support and assistance of the NASA Polar Program manager, W. Abdalati. We also thank $R$. Thomas, an anonymous reviewer and the scientific editor, W. Harrison, for their efforts in improving the paper.

\section{REFERENCES}

Abdalati, W. and 9 others. 2001. Outlet glacier and margin elevation changes: near-coastal thinning of the Greenland ice sheet. J. Geophys. Res., 106(D24), 33,729-33,742.

Andreasen, J.O. 1985. Seasonal surface-velocity variations on a subpolar glacier in West Greenland. J. Glaciol., 31(109), 319-323.

Arendt, A.A., K.A. Echelmeyer, W.D. Harrison, C.S. Lingle and V.B. Valentine. 2002. Rapid wastage of Alaska glaciers and their contribution to rising sea level. Science, 297(5580), 382-386.

Arthern, R.J. and D.J. Wingham. 1998. The natural fluctuations of firn densification and their effect on the geodetic determination of ice sheet mass balance. Climatic Change, 40(4), 605-624.
Bamber, J.L., W.B. Krabill, V. Raper and J.A. Dowdeswell. 2004. Anomalous growth of part of a large Arctic ice cap: Austfonna, Svalbard. Geophys. Res. Lett., 31(12), L12402. (10.1029/ 2004GL019667.)

Bamber, J., W. Krabill, V. Raper and J. Dowdeswell. 2005. Elevation changes measured on Svalbard glaciers and ice caps from airborne laser data. Ann. Glaciol., 42 (see paper in this volume).

Comiso, J.C. 1995. SSM/I sea ice concentrations using the Bootstrap algorithm. NASA Ref. Publ. 1380.

Dare, R.A. and B.W. Atkinson. 1999. Numerical modeling of atmospheric response to polynyas in the Southern Ocean sea ice zone. J. Geophys. Res., 104(D14), 16,691-16,708.

Dowdeswell, J.A. and J.O. Hagen. 2004. Arctic glaciers and ice caps. In Bamber, J.L. and A.J. Payne, eds. Mass balance of the cryosphere: observations and modelling of contemporary and future changes. Cambridge, etc., Cambridge University Press, 527-557.

Dowdeswell, J.A., D.J. Drewry, A.P.R. Cooper, M.R. Gorman, O. Liestøl and O. Orheim. 1986. Digital mapping of the Nordaustlandet ice caps from airborne geophysical investigations. Ann. Glaciol., 8, 51-58.

Dowdeswell, J.A., R. Hodgkins, A.-M. Nuttall, J.O. Hagen and G.S. Hamilton. 1995. Mass balance change as a control on the frequency and occurrence of glacier surges in Svalbard, Norwegian High Arctic. Geophys. Res. Lett., 22(21), 2909-2912.

Dowdeswell, J.A., B. Unwin, A.-M. Nuttall and D.J. Wingham. 1999. Velocity structure, flow instability and mass flux on a large Arctic ice cap from satellite radar interferometry. Earth Planet. Sci. Lett., 167(3-4), 131-140.

Hagen, J.O., O. Liestøl, E. Roland and T. Jørgensen. 1993. Glacier atlas of Svalbard and Jan Mayen. Nor. Polarinst. Medd. 129.

Hagen, J.O., K. Melvold, F. Pinglot and J. Dowdeswell. 2003. On the net mass balance of the glaciers and ice caps in Svalbard, Norwegian Arctic. Arct. Antarct. Alp. Res., 35(2), 264-270.

Isaksson, E. and 14 others. 2001. A new ice-core record from Lomonosovfonna, Svalbard: viewing the 1920-97 data in relation to present climate and environmental conditions. J. Glaciol., 47(157), 335-345.

Ivanov, B.V., S. Gerland, J.G. Winther and H. Goodwin. 2003. Energy exchange processes in the marginal ice zone of Barents Sea, Arctic Ocean, during spring 1999. J. Glaciol., 49(166), 415-419.

Jiskoot, H., T. Murray and P. Boyle. 2000. Controls on the distribution of surge-type glaciers in Svalbard. J. Glaciol., 46(154), 412-422.

Krabill, W.B., R.H. Thomas, C.F. Martin, R.N. Swift and E.B. Frederick. 1995a. Accuracy of airborne laser altimetry over the Greenland ice sheet. Int. J. Remote Sensing, 16(7), 1211-1222. 
Krabill, W., R. Thomas, K. Jezek, K. Kuivinen and S. Manizade. 1995b. Greenland ice sheet thickness changes measured by laser altimetry. Geophys. Res. Lett., 22(17), 2341-2344.

Krabill, W. and 8 others. 1999. Rapid thinning of parts of the southern Greenland ice sheet. Science, 283(5407), 1522-1524.

Krabill, W. and 9 others. 2000. Greenland ice sheet: high-elevation balance and peripheral thinning. Science, 289(5478), 428-430.

Lefauconnier, B. and J.O. Hagen. 1991. Surging and calving glaciers in eastern Svalbard. Nor. Polarinst. Medd. 116.

McConnell, J.R. and 7 others. 2000. Changes in Greenland ice sheet elevation attributed primarily to snow accumulation variability. Nature, 406(6798), 877-879.

Melvold, K. and J.O. Hagen. 1998. Evolution of a surge-type glacier in its quiescent phase: Kongsvegen, Spitsbergen, 1964-95. J. Glaciol., 44(147), 394-404.
Pinglot, J.F., J.O. Hagen, K. Melvold, T. Eiken and C. Vincent. 2001. A mean net accumulation pattern derived from radioactive layers and radar soundings on Austfonna, Nordaustlandet, Svalbard. J. Glaciol., 47(159), 555-566.

Singarayer, J.S. and J.L. Bamber. 2003. EOF analysis of three records of sea-ice concentration spanning the last 30 years. Geophys. Res. Lett., 30(5), 1251. (10.1029/2002GL016640.)

Unwin, B. and D. Wingham. 1997. Topography and dynamics of Austfonna, Nordaustlandet, Svalbard, from SAR interferometry. Ann. Glaciol., 24, 403-408.

Wingham, D.J., A.L. Ridout, R. Scharroo, R.J. Arthern and C.K. Shum. 1998. Antarctic elevation change 1992 to 1996. Science, 282(5388), 456-458.

Zwally, H.J. and J. Li. 2002. Seasonal and interannual variations of firn densification and ice-sheet surface elevation at Greenland summit. J. Glaciol., 48(161), 199-207. 